\title{
MOTERŲ, SERGANČIŲ KRŪTIES VE்ŽIU, ASMENYBĖS BRUOŽŲ BEI STRESO, SUSIJUSIO SU LIGA, IVEIKIMO STRATEGIJŲ SĄSAJOS SU SVEIKATA SUSIJUSIA GYVENIMO KOKYBE
}

\author{
Irina Baniené $\dot{1}^{1}$ Liuda Šinkariova ${ }^{2}$ \\ ${ }^{1}$ Lietuvos sveikatos moksly universitetas, ${ }^{2}$ Vytauto Didžiojo universitetas
}

Raktažodžiai: moterys, krūties vėžys, asmenybès bruožai, streso ịveikimo strategijos, su sveikata susijusi gyvenimo kokybè.

\begin{abstract}
Santrauka
Tyrimo tikslas - nustatyti moterų, sergančių krūties vèžiu, asmenybès bruožų bei streso, susijusio su liga, įveikimo strategijų sąsajas su sveikata susijusia gyvenimo kokybe. Tyrime dalyvavo 102 krūties věžiu sergančios moterys, kurios buvo atrenkamos pagal šiuos kriterijus: moteriška lytis; nustatyta I - II krūties véžio stadija; prieš 1-2 mènesius atliktas operacinis gydymas; prieš operacini gydymą netaikytas chemoterapinis ar spindulinis gydymas; dèl véžio ligos gydosi pirmą kartą; sutikusios dalyvauti tyrime. Tiriamųjų apklausai naudoti šie klausimynai: Eysenck asmenybės klausimynas EPI (ang. Eysenck's personality Inventory); stresogeninių situacijų ịveikos klausimynas COPE (angl. Coping Orientation of Problem Experience); Europos vèžio gydymo ir tyrimo organizacijos (angl. EORTC Quality of Life Group) gyvenimo kokybès klausimynas EORTC QLQ - C30 ir jo modulis EORTC QLQ - BR23. Tyrimo rezultatai parode, kad krūties vèžiu sergančios moterys, pasižyminčios aukštesniais ekstraversiškumo rodikliais, savo bendrą su sveikata susijusią gyvenimo kokybę bei seksualinị funkcionavimą suvokia kaip geresnį, palyginus su moterimis, pasižyminčiomis aukštesniais neurotiškumo bei psichotiškumo rodikliais. Moterys, dažniau naudojančios adaptyvias streso įveikimo strategijas, savo bendrą su sveikata susijusią gyvenimo kokybę, emocinį, kognityvinị bei seksualinị funkcionavimą vertina kaip geresnius ir jaučia mažesnę baimę dèl ateities, palyginus su moterimis, dažniau naudojančiomis mažiau adaptyvias įveikimo strategijas. Krūties véžiu sergančių moteru geresnę bendrą su sveikata susijusią gyvenimo kokybę paaiškina daž-
\end{abstract}

nesnis adaptyvaus ị emocijas nukreipto ịveikimo bei retesnis mažiau adaptyvaus įveikimo naudojimas.

\section{Ivadas}

Krūties vėžys - dažniausia moterų onkologinė liga tiek ekonomiškai išsivysčiusiose, tiek besivystančiose šalyse [1]. Nežiūrint ị didèjantị sergamumą, tobulèjant medicinai, ilgèja věžiu sergančių asmenų gyvenimo trukmè, todèl vis aktualesni tampa ir jomis sergančių asmenų gyvenimo kokybės klausimai.

Krūties vėžio gydymas trunka ilgai, yra sudètingas ir gali kelti nemažai psichologinių sunkumų. Nežiūrint ị tai, krūties věžiu sergančios moterys skirtingai prisitaiko prie ligos bei skirtingai vertina savo gyvenimo kokybę. Viena iš priežasčių - ịveikos strategijų naudojimas. Dauguma tyrẻjų teigia, kad kiekvienas, sergantis onkologine liga žmogus, individualiai pasirenka ịveikos strategijas, kurios jam padeda kovoti su ligos simptomais ir pasekmèmis, siekiant gyvenimo gerovès ir fizinès bei psichinès sveikatos gerinimo [2]. Streso ịveikimo strategijų pasirinkimas priklauso nuo daugybės faktorių, yra duomenų, kad įveikos pasirinkimas susijęs ir su asmenybès ypatumais [3].

Hipotezès: 1. Krūties véžiu sergančios moterys, pasižyminčios aukštesniais ekstraversiškumo rodikliais, savo su sveikata susijusią gyvenimo kokybę suvokia kaip geresnę, palyginus su moterimis, pasižyminčiomis aukštesniais neurotiškumo bei psichotiškumo rodikliais. 2. Krūties vèžiu sergančios moterys, dažniau naudojančios adaptyvias streso įveikimo strategijas, savo su sveikata susijusią gyvenimo kokybę suvokia kaip geresnę, palyginus su moterimis, dažniau naudojančiomis mažiau adaptyvias ịveikimo strategijas. 3. Krūties vẻžiu sergančių moterų geresnę bendrą su sveikata susijusią gyvenimo kokybę paaiškina ekstraversiškumas bei dažnesnis adaptyvių streso įveikimo strategijų naudojimas.

Tyrimo tikslas - nustatyti moterų, sergančių krūties vèžiu, asmenybės bruožų bei streso, susijusio su liga, ịveikimo strategijų sąsajas su sveikata susijusia gyvenimo kokybe. 


\section{Tyrimo objektas ir metodai}

Tyrimas atliktas $2011 \mathrm{~m}$. sausio - kovo mènesiais, jame dalyvavo 102 krūties vèžiu sergančios moterys, kurios buvo atrinktos pagal šiuos kriterijus: moteriška lytis, nustatyta I-II krūties vèžio stadija, prieš 1-2 mènesius atliktas operacinis gydymas, prieš chirurginį gydymą neatliktas chemoterapinis ar spindulinis gydymas, dèl vėžio gydosi pirmą kartą, sutikimas dalyvauti tyrime. Jauniausiai tyrime dalyvavusiai respondentei 30 metų, vyriausiai - 72 metai, vidurkis 53,96 metai. Šiame darbe lyginant tiriamąsias pagal sociodemografinius rodiklius jos buvo suskirstytos i grupes: jaunesnès (iki 53 metų) $(n=56 ; 54,9 \%)$ ir vyresnès (nuo 54 metų) $(\mathrm{n}=46 ; 45,1 \%)$, aukštajį išsilavinimą $(\mathrm{n}=68$; $66,7 \%)$ ir žemesni už aukštaji išsilavinimą ( $\mathrm{n}=34 ; 33,3 \%)$ turinčios, gyvenančios su partneriu $(\mathrm{n}=60 ; 58,8 \%)$ ir gyvenančios be partnerio $(n=42 ; 41,2 \%)$, dirbančios $(n=60$; $82,2 \%)$ ir nedirbančios $(\mathrm{n}=13 ; 17,8 \%)$ moterys.

Tyrime buvo naudojama matavimo priemonè, sudary-

1 lentelè. Gyvenimo kokybès vidutinių rangų palyginimas skirtingais asmenybės bruožais pasižyminčiose moterų grupèse (Mann-Whithey U testas)

\begin{tabular}{|c|c|c|c|c|c|c|c|}
\hline \multirow{3}{*}{ Gyvenimo kokybės skalės } & \multicolumn{3}{|c|}{ Ekstraversiškumas } & \multicolumn{3}{|c|}{ Psichotiškumas } & \multirow{3}{*}{$\mathbf{p}$} \\
\hline & \multicolumn{3}{|c|}{$\mathrm{N}=30$} & \multicolumn{3}{|c|}{$\mathrm{N}=33$} & \\
\hline & $\begin{array}{c}\text { Vidutinis } \\
\text { rangas }\end{array}$ & Vidurkis & $\begin{array}{c}\text { Standartinis } \\
\text { nuokrypis }\end{array}$ & $\begin{array}{l}\text { Vidutinis } \\
\text { rangas }\end{array}$ & Vidurkis & $\begin{array}{l}\text { Standartinis } \\
\text { nuokrypis }\end{array}$ & \\
\hline Bendra gyvenimo kokybė & 37,10 & 58,33 & 21,66 & 27,36 & 49,49 & 16,79 & $\mathbf{0 , 0 3}$ \\
\hline Simptomų skalè & 30,57 & 38,68 & 21,68 & 33,30 & 34,64 & 10,08 & 0,55 \\
\hline Emocinis funkcionavimas & 29,57 & 58,89 & 29,92 & 34,21 & 66,67 & 28,79 & 0,31 \\
\hline Kognityvinis funkcionavimas & 34,93 & 74,44 & 28,94 & 29,33 & 70,71 & 20,43 & 0,21 \\
\hline Kūno vaizdas & 34,57 & 63,33 & 38,88 & 29,67 & 54,55 & 30,55 & 0,29 \\
\hline Seksualinis funkcionavimas & 37,70 & 23,33 & 29,56 & 26,82 & 4,04 & 9,35 & 0,004 \\
\hline Baimė dèl ateities & 29,83 & 22,22 & 31,96 & 33,97 & 29,29 & 30,91 & 0,31 \\
\hline \multirow{3}{*}{ Gyvenimo kokybės skalės } & \multicolumn{3}{|c|}{ Ekstraversiškumas } & \multicolumn{3}{|c|}{ Neurotiškumas } & \multirow{3}{*}{$\mathbf{p}$} \\
\hline & \multicolumn{3}{|c|}{$\mathrm{N}=30$} & \multicolumn{3}{|c|}{$\mathrm{N}=39$} & \\
\hline & $\begin{array}{l}\text { Vidutinis } \\
\text { rangas }\end{array}$ & Vidurkis & $\begin{array}{l}\text { Standartinis } \\
\text { nuokrypis }\end{array}$ & $\begin{array}{l}\text { Vidutinis } \\
\text { rangas }\end{array}$ & Vidurkis & $\begin{array}{l}\text { Standartinis } \\
\text { nuokrypis }\end{array}$ & \\
\hline Bendra gyvenimo kokybė & 41,30 & 58,33 & 21,66 & 30,15 & 48,72 & 16,94 & 0,02 \\
\hline Simptomų skalė & 31,23 & 38,68 & 21,68 & 37,90 & 40,71 & 16,80 & 0,17 \\
\hline Emocinis funkcionavimas & 35,63 & 58,89 & 29,92 & 34,51 & 56,84 & 30,64 & 0,82 \\
\hline Kognityvinis funkcionavimas & 34,80 & 74,44 & 28,94 & 35,15 & 73,50 & 30,52 & 0,94 \\
\hline Kūno vaizdas & 39,63 & 63,33 & 38,88 & 31,44 & 48,29 & 32,11 & 0,09 \\
\hline Seksualinis funkcionavimas & 35,50 & 23,33 & 29,56 & 34,62 & 19,66 & 23,53 & 0,85 \\
\hline Baimė dèl ateities & 35,50 & 22,22 & 31,96 & 34,62 & 17,95 & 27,41 & 0,83 \\
\hline \multirow{3}{*}{ Gyvenimo kokybės skalės } & \multicolumn{3}{|c|}{ Psichotiškumas } & \multicolumn{3}{|c|}{ Neurotiškumas } & \multirow{3}{*}{$\mathbf{p}$} \\
\hline & \multicolumn{3}{|c|}{$\mathrm{N}=33$} & \multicolumn{3}{|c|}{$\mathrm{N}=39$} & \\
\hline & $\begin{array}{l}\text { Vidutinis } \\
\text { rangas }\end{array}$ & Vidurkis & $\begin{array}{l}\text { Standartinis } \\
\text { nuokrypis }\end{array}$ & $\begin{array}{l}\text { Vidutinis } \\
\text { rangas }\end{array}$ & Vidurkis & $\begin{array}{l}\text { Standartinis } \\
\text { nuokrypis }\end{array}$ & \\
\hline Bendra gyvenimo kokybė & 36,02 & 49,49 & 16,79 & 36,91 & 48,72 & 16,94 & 0,85 \\
\hline Simptomų skalè & 31,62 & 34,64 & 10,08 & 40,63 & 40,71 & 16,80 & 0,07 \\
\hline Emocinis funkcionavimas & 40,20 & 66,67 & 28,79 & 33,37 & 56,84 & 30,64 & 0,17 \\
\hline Kognityvinis funkcionavimas & 33,29 & 70,71 & 20,43 & 39,22 & 73,50 & 30,52 & 0,22 \\
\hline Kūno vaizdas & 38,41 & 54,55 & 30,55 & 34,88 & 48,29 & 32,11 & 0,47 \\
\hline Seksualinis funkcionavimas & 29,14 & 4,04 & 9,35 & 42,73 & 19,66 & 23,53 & 0,001 \\
\hline Baimè dèl ateities & 40,38 & 29,29 & 30,91 & 33,22 & 17,95 & 27,41 & 0,11 \\
\hline
\end{tabular}


2 lentelè. Gyvenimo kokybès vidutinių rangų palyginimas pagal streso ịveikimo strategijų naudojimą (Mann-Whithey U testas)

\begin{tabular}{|c|c|c|c|c|c|c|c|}
\hline \multirow{3}{*}{ Gyvenimo kokybės skalès } & \multicolumn{3}{|c|}{$\begin{array}{c}\text { Adaptyvus ị problemą nukreiptas } \\
\text { ịveikimas }\end{array}$} & \multicolumn{3}{|c|}{$\begin{array}{c}\text { Adaptyvus ị emocijas nukreiptas } \\
\text { ịveikimas }\end{array}$} & \multirow{3}{*}{$\mathbf{p}$} \\
\hline & \multicolumn{3}{|c|}{$N=36$} & \multicolumn{3}{|c|}{$\mathbf{N}=32$} & \\
\hline & $\begin{array}{l}\text { Vidutinis } \\
\text { rangas }\end{array}$ & Vidurkis & $\begin{array}{l}\text { Standartinis } \\
\text { nuokrypis }\end{array}$ & $\begin{array}{l}\text { Vidutinis } \\
\text { rangas }\end{array}$ & Vidurkis & $\begin{array}{l}\text { Standartinis } \\
\text { nuokrypis }\end{array}$ & \\
\hline Bendra gyvenimo kokybė & 37,44 & 57,41 & 18,45 & 31,19 & 52,60 & 14,88 & 0,19 \\
\hline Simptomų skalè & 34,22 & 35,19 & 12,43 & 34,81 & 35,80 & 16,12 & 0,90 \\
\hline Emocinis funkcionavimas & 34,53 & 68,52 & 23,24 & 34,47 & 68,75 & 22,30 & 0,99 \\
\hline $\begin{array}{l}\text { Kognityvinis } \\
\text { funkcionavimas }\end{array}$ & 33,67 & 77,31 & 23,96 & 35,44 & 81,25 & 18,81 & 0,70 \\
\hline Kūno vaizdas & 31,19 & 53,47 & 35,49 & 38,22 & 66,67 & 26,10 & 0,14 \\
\hline Seksualinis funkcionavimas & 35,61 & 22,22 & 23,90 & 33,25 & 19,79 & 27,58 & 0,60 \\
\hline Baimė dèl ateities & 31,94 & 25,93 & 30,97 & 37,38 & 35,42 & 32,72 & 0,22 \\
\hline \multirow{3}{*}{ Gyvenimo kokybės skalès } & \multicolumn{3}{|c|}{$\begin{array}{c}\text { Adaptyvus ị problemą nukreiptas } \\
\text { ịveikimas }\end{array}$} & \multicolumn{3}{|c|}{ Mažiau adaptyvus ịveikimas } & \multirow{3}{*}{$\mathbf{p}$} \\
\hline & \multicolumn{3}{|c|}{$\mathrm{N}=36$} & \multicolumn{3}{|c|}{$\mathrm{N}=\mathbf{3 4}$} & \\
\hline & $\begin{array}{l}\text { Vidutinis } \\
\text { rangas }\end{array}$ & Vidurkis & $\begin{array}{l}\text { Standartinis } \\
\text { nuokrypis }\end{array}$ & $\begin{array}{l}\text { Vidutinis } \\
\text { rangas }\end{array}$ & Vidurkis & $\begin{array}{l}\text { Standartinis } \\
\text { nuokrypis }\end{array}$ & \\
\hline Bendra gyvenimo kokybė & 40,67 & 57,41 & 18,45 & 30,03 & 45,10 & 20,53 & $\mathbf{0 , 0 2}$ \\
\hline Simptomų skalè & 31,42 & 35,19 & 12,43 & 39,82 & 43,50 & 20,12 & 0,08 \\
\hline Emocinis funkcionavimas & 42,03 & 68,52 & 23,24 & 28,59 & 44,61 & 35,94 & 0,01 \\
\hline $\begin{array}{l}\text { Kognityvinis } \\
\text { funkcionavimas }\end{array}$ & 40,64 & 77,31 & 23,96 & 30,06 & 60,29 & 32,05 & $\mathbf{0 , 0 3}$ \\
\hline Kūno vaizdas & 37,78 & 53,47 & 35,49 & 33,09 & 44,85 & 36,35 & 0,33 \\
\hline Seksualinis funkcionavimas & 42,42 & 22,22 & 23,90 & 28,18 & 4,90 & 13,93 & $<0,001$ \\
\hline Baimè dèl ateities & 40,61 & 25,93 & 30,97 & 30,09 & 7,84 & 18,46 & $\mathbf{0 , 0 1}$ \\
\hline \multirow{3}{*}{ Gyvenimo kokybės skalès } & \multicolumn{3}{|c|}{$\begin{array}{c}\text { Adaptyvus ị emocijas nukreiptas } \\
\text { ịveikimas }\end{array}$} & \multicolumn{3}{|c|}{ Mažiau adaptyvus įveikimas } & \multirow{3}{*}{$\mathbf{p}$} \\
\hline & \multicolumn{3}{|c|}{$\mathrm{N}=32$} & \multicolumn{3}{|c|}{$\mathrm{N}=34$} & \\
\hline & $\begin{array}{l}\text { Vidutinis } \\
\text { rangas }\end{array}$ & Vidurkis & $\begin{array}{l}\text { Standartinis } \\
\text { nuokrypis }\end{array}$ & $\begin{array}{l}\text { Vidutinis } \\
\text { rangas }\end{array}$ & Vidurkis & $\begin{array}{l}\text { Standartinis } \\
\text { nuokrypis }\end{array}$ & \\
\hline Bendra gyvenimo kokybè & 36,88 & 52,60 & 14,88 & 30,32 & 45,10 & 20,53 & 0,15 \\
\hline Simptomų skalė & 29,88 & 35,80 & 16,12 & 36,91 & 43,50 & 20,12 & 0,14 \\
\hline Emocinis funkcionavimas & 40,03 & 68,75 & 22,30 & 27,35 & 44,61 & 35,94 & 0,01 \\
\hline $\begin{array}{l}\text { Kognityvinis } \\
\text { funkcionavimas }\end{array}$ & 39,69 & 81,25 & 18,81 & 27,68 & 60,29 & 32,05 & 0,01 \\
\hline Kūno vaizdas & 40,16 & 66,67 & 26,10 & 27,24 & 44,85 & 36,35 & $\mathbf{0 , 0 1}$ \\
\hline Seksualinis funkcionavimas & 39,56 & 19,79 & 27,58 & 27,79 & 4,90 & 13,93 & $\mathbf{0 , 0 0 3}$ \\
\hline Baimè dèl ateities & 41,69 & 35,42 & 32,72 & 25,79 & 7,84 & 18,46 & $<0,001$ \\
\hline
\end{tabular}


ta iš 4 dalių: 1. H. ir S. Eysenck asmenybès klausimynas (EPI). Klausimyną sudaro 101 teiginys, jame išskiriamos keturios skalès: ekstraversija - intraversija; neurotizmas emocinis stabilumas, psichotizmas (rigidiškumas), socialinis patrauklumas (melo skalè). Tyrime naudojome tris skales, jų vidini patikimumą vertinome Kronbach'o alfa koeficientu: ekstraversiškumo $(\alpha=0,7)$, psichotiškumo $(\alpha=0,7)$ bei neurotiškumo $(\alpha=0,8)$. 2. Iveikos strategijų klausimynas (COPE). COPE klausimyną sudaro 60 teiginių. Prie kiekvieno teiginio tiriamųų prašoma ịvertinti, kiek būdingas toks elgesys susidūrus su liga. Kiekvieną teiginyje aprašytą elgesio būdą prašoma ịvertinti 4 balų Likerto skale nuo „niekada“ (1 balas) iki „labai dažnai“ (4 balai). Kuo didesnis skalès įvertinimas, tuo labiau tiriamasis yra linkęs naudoti pastarąa ịveikos strategiją. Išskiriamos 15 streso ìveikimo strategijų, kurios sugrupuotos pagal adaptyvumą bei orientaciją: adaptyvus i problemą nukreiptas ịveikimas $(\alpha=0,7)$, adaptyvus ị emocijas nukreiptas ịveikimas $(\alpha=0,6)$, mažiau adaptyvus ịveikimas $(\alpha=0,6)$. 3. Europos véžio gydymo ir tyrimo organizacijos gyvenimo kokybès klausimynas EORTC QLQ - C30 ir jo modulis EORTC QLQ - BR23. EORTC QLQ - C30 sudaro bendros gyvenimo kokybès skale $(\alpha=0,7)$, funkcionavimo ir simptomy skalès (30 klausimų). Šiame tyrime funkcionavimą apibūdina emocinio $(\alpha=0,9)$ ir kognityvinio $(\alpha=0,6)$ funkcionavimo skalès. EORTC QLQ - BR23 klausimynas yra pritaikytas krūties véžiu sergančių ligonių tyrimui. Klausimyną sudaro funkcionavimo ir simptomų skalès (23 klausimai). Šiame tyrime funkcionavimą apibūdina: kūno įvaizdis $(\alpha=0,9)$ ir seksualinis funkcionavimas $(\alpha=0,9)$. EORTC QLQ - C30 klausimyno simptomų skalemis vertinamas pašalinis gydymo poveikis, su krūtimi susiję simptomai, su rankos funkcionavimu susiję simptomai ir jaudinimasis dèl plaukų slinkimo. QLQ - BR23 klausimyno simptomų skalemis vertinamas silpnumas, pykinimas ir vėmimas, skausmas, dusulys, miego sutrikimai, apetito sutrikimai, vidurių užkietejjimas, viduriavimas ir finansiniai sunkumai. Visos simptomų skalès iš EORTC QLQ - C30 ir QLQ - BR23 klausimynų buvo sujungtos į vieną bendrą simptomų skalę $(\alpha=0,9)$. Bendros gyvenimo kokybès ir funkcionavimo skalèse aukštesnis rezultatas atitinka geresnę gyvenimo kokybę, simptomų skalès aukštesnis rezultatas rodo didesnį simptomo ryškumą. 4. Anketa - bendriesiems duomenims apie tiriamuosius surinkti.

Tyrimo dalyvès buvo supažindintos su tyrimo tikslu, joms individualiai buvo paaiškinta, kaip pildyti klausimynus, ir tai jos atliko savarankiškai. Kiekviena sutikusi dalyvauti tyrime moteris pasirašè informuotą sutikimą. Respondentėms buvo garan- tuotas konfidencialumas.

Statistinè analizė atlikta naudojant statistinį duomenų analizès paketą SPSS 17.0. Taikyti aprašomosios statistikos, Kruskalo-Woleso analizès, Mann-Whithey U testo, logistinè regresinès analizès metodai. Hipotezių tikrinimui pasirinktas 0,05 reikšmingumo lygmuo.

\section{Rezultatai}

Siekiant patikrinti 1-mą hipotezę, kad krūties vėžiu sergančios moterys, pasižyminčios aukštesniais ekstraversiškumo rodikliais, savo su sveikata susijusią gyvenimo kokybę suvokia kaip geresnę, palyginus su moterimis, pasižyminčiomis aukštesniais neurotiškumo bei psichotiškumo rodikliais, atliktas gyvenimo kokybės vidutinių rangu palyginimas skirtingais asmenybès bruožais pasižyminčiose moteru grupèse (1lentelè). Nustatyta, kad ekstraversiškumu pasižyminčios moterys statistiškai reikšmingai dažniau savo bendrą gyvenimo kokybę suvokia kaip geresnę, negu psichotiškumu bei neurotiškumu pasižyminčios moterys $(\mathrm{p}=0,03, \mathrm{p}=0,02)$, o seksualini funkcionavimą vertina kaip geresnị, palyginus su psichotiškumu pasižyminčiomis moterimis $(\mathrm{p}=0,004)$. Taip pat nustatyta, kad neurotiškumu pasižyminčios moterys statistiškai reikšmingai dažniau savo seksualinį funkcionavimą vertina kaip geresnį, palyginus su psichotiškumu pasižyminčiomis moterimis $(\mathrm{p}=0,001)$.

Siekiant patikrinti 2-ą hipotezę, ar krūties vèžiu sergančios moterys, dažniau naudojančios adaptyvias streso ịveikimo strategijas, savo su sveikata susijusią gyvenimo kokybę suvokia kaip geresnę, palyginus su moterimis, dažniau naudojančiomis mažiau adaptyvias įveikimo strategijas, palyginome gyvenimo kokybès vidutinius rangus skirtingas streso ịveikimo strategijas linkusiose naudoti moteru

3 lentelè. Bendros gyvenimo kokybès ryšys su nepriklausomais kintamaisiais

\begin{tabular}{|l|c|c|c|c|}
\hline \multicolumn{1}{|c|}{$\begin{array}{c}\text { Nepriklausomi } \\
\text { kintamieji }\end{array}$} & $\begin{array}{c}\text { Koeficientų } \\
\text { reikšmės }\end{array}$ & $\begin{array}{c}\text { Wald'o } \\
\text { kriterijus }\end{array}$ & $\mathbf{p}$ & $\begin{array}{c}\text { Galimybių } \\
\text { santykis }\end{array}$ \\
\hline Ekstraversiškumas & 0,147 & 2,89 & 0,09 & 1,16 \\
\hline Psichotiškumas & 0,159 & 0,58 & 0,44 & 1,17 \\
\hline Neurotiškumas & 0,041 & 0,28 & 0,59 & 1,04 \\
\hline $\begin{array}{l}\text { Adaptyvus ị problemą } \\
\text { nukreiptas įveikimas }\end{array}$ & 0,083 & 0,01 & 0,92 & 1,09 \\
\hline $\begin{array}{l}\text { Adaptyvus ị emocijas } \\
\text { nukreiptas ịveikimas }\end{array}$ & 1,962 & 4,82 & $\mathbf{0 , 0 3}$ & 7,11 \\
\hline $\begin{array}{l}\text { Mažiau adaptyvus } \\
\text { iveikimas }\end{array}$ & $-4,233$ & 13,95 & $<\mathbf{0 , 0 0 1}$ & 0,01 \\
\hline Amžius & 0,694 & 1,28 & 0,26 & 2,00 \\
\hline Išsilavinimas & $-0,705$ & 1,00 & 0,32 & 0,49 \\
\hline Šeiminė padėtis & 0,837 & 1,79 & 0,18 & 2,31 \\
\hline Užimtumas & 0,992 & 1,10 & 0,29 & 2,70 \\
\hline Konstanta & $-1,267$ & 0,17 & 0,68 & 0,28 \\
\hline
\end{tabular}


grupèse. Prieš tai moterys buvo suskirstytos ị tris grupes pagal streso ịveikimo strategijų naudojimo dažnumą (2 lentelè). Nustatyta, kad moterys, dažniau linkusios naudoti adaptyvų i problemą nukreiptą įveikimą, statistiškai reikšmingai dažniau savo bendrą gyvenimo kokybę $(p=0,02)$, emocini $(p=0,01)$, kognityvini $(p=0,03)$ bei seksualini $(p<0,001)$ funkcionavimą vertina kaip geresnius ir jaučia mažesnę baimę dèl ateities $(\mathrm{p}=0,01)$, palyginus su moterimis, linkusiomis dažniau naudoti mažiau adaptyvų įveikimą. Tuo tarpu moterys, dažniau linkusios naudoti adaptyvų i emocijas nukreiptą įveikimą, statistiškai reikšmingai dažniau savo emocini $(p=0,01)$, kognityvini $(p=0,01)$, seksualinị $(\mathrm{p}=0,003)$ funkcionavimą bei kūno vaizdą $(\mathrm{p}=0,01)$ vertina kaip geresnius ir jaučia mažesnę baimę dèl ateities $(p<0,001)$, palyginus su moterimis, linkusiomis dažniau naudoti mažiau adaptyvų įveikimą.

Siekiant išsiaiškinti 3 hipotezę, kad krūties vėžiu sergančių moterų geresnę bendrą su sveikata susijusią gyvenimo kokybę paaiškina ekstraversiškumas bei dažnesnis adaptyvių streso įveikimo strategijų naudojimas, buvo atlikta logistinè regresiné analizè, kurioje priklausomu kintamuoju buvo bendra gyvenimo kokybė (3 lentelè). Modelio $\chi^{2}$ suderinamumo kriterijus rodo, kad logistinès regresijos modelis egzistuoja $(p<0,001)$ bei Hosmer-Lemeshow kriterijus rodo, kad logistinès regresijos modelis su duomenimis suderintas $(\mathrm{p}=0,782)$. Modelio prognozavimo tikslumas yra $78,4 \%$ (pakankamas).

Iš lentelèje pateiktų rezultatų (3 lentelè) matyti, kad kai krūties véžiu sergančios moterys naudoja adaptyvų ị emocijas nukreiptą ịveikimą, tikimybe savo bendrą gyvenimo kokybę suvokti kaip geresnę yra 7,1 karto didesnè nei naudojant kitas iqveikimo strategijas $(\mathrm{p}=0,03)$. Nustatyta, kad kuo dažniau moterys naudoja mažiau adaptyvų ịveikimą, tuo jų bendra gyvenimo kokybė yra blogesnè $(p<0,001)$. Kiti modelyje naudoti nepriklausomi kintamieji nèra statistiškai reikšmingai susiję su bendra gyvenimo kokybe $(\mathrm{p}>0,05)$.

\section{Rezultatų aptarimas}

Analizuodami gyvenimo kokybès rodiklius skirtingais asmenybès bruožais (ekstraversiškumu, psichotiškumu, neurotiškumu) pasižyminčiose krūties vėžiu sergančių moterų grupėse, nustatėme, kad ekstraversiškumu pasižyminčios moterys dažniau savo bendrą gyvenimo kokybę bei seksualini funkcionavimą suvokia kaip geresnius, palyginus su kitais asmenybės bruožais (neurotiškumu, psichotiškumu) pasižyminčiomis moterimis. Galima sakyti, kad tai sutampa su kitų autorių tyrimų rezultatais [4], kurie nustatè, kad introversiškumas bei neurotiškumas susiję su blogesniais gyvenimo kokybès rodikliais. O tyrimas, atliktas su vėžiu sergančiais pacientais, parodè, kad neurotizmas teigiamai koreliuoja su depresija, susirūpinimu, blogesne gyvenimo kokybe ir neviltimi [5].

Mūsų duomenimis, moterys, dažniau naudojančios adaptyvias streso įveikimo strategijas (adaptyvų i problemą nukreipta ịveikimą ir adaptyvų i emocijas nukreipta įveikimą), savo gyvenimo kokybę vertina kaip geresnę, palyginus su moterimis, dažniau naudojančiomis mažiau adaptyvias streso ịveikimo strategijas. Tai patvirtina tyrimo, atlikto su onkologinèmis ligomis sergančiais pacientais, rezultatus, kad aukštą neurotizmo lygi turintys asmenys dažniau naudoja vengimo įveikos strategijas, o tai susiję su blogesne subjektyviai vertinama gyvenimo kokybe, ligos simptomų išreikštumu [3].

Tyrimas atskleide, kad vienas iš svarbiausiu veiksnių, paaiškinančiu geresnius su sveikata susijusios gyvenimo kokybės rodiklius, yra retesnis mažiau adaptyvaus ịveikimo naudojimas. Šiame darbe mažiau adaptyvus įveikimas apima koncentravimosi i jausmus ir jų išreiškimą, elgesio pakeitimo (pasyvaus elgesio), mąstymo pakeitimo (vengimo), svaigalų vartojimo strategijas. Kitų autorių atliktas tyrimas parode, jog mažiau adaptyvios (vengimo, pasyvumo, apatijos, atmetimo ir kt.) ịveikos susijusios su blogesniais gyvenimo kokybės rodikliais [8].

\section{Išvados}

1. Krūties vėžiu sergančios moterys, pasižyminčios aukštesniais ekstraversiškumo rodikliais, savo bendrą su sveikata susijusią gyvenimo kokybę bei seksualini funkcionavimą suvokia kaip geresni, palyginus su moterimis, pasižyminčiomis aukštesniais neurotiškumo bei psichotiškumo rodikliais.

2. Krūties vèžiu sergančios moterys, dažniau naudojančios adaptyvias streso ịveikimo strategijas, savo bendrą su sveikata susijusią gyvenimo kokybę, emocinį, kognityvinį bei seksualinį funkcionavimą vertina kaip geresnius ir jaučia mažesnę baimę dèl ateities, palyginus su moterimis, dažniau naudojančiomis mažiau adaptyvias įveikimo strategijas.

3. Krūties vèžiu sergančių moterų geresnę bendrą su sveikata susijusią gyvenimo kokybę paaiškina dažnesnis adaptyvaus $i$ emocijas nukreipto įveikimo bei retesnis mažiau adaptyvaus ịveikimo naudojimas.

\section{Literatūra}

1. Prieiga per internetą: http://globocan.iarc.fr/old/FactSheets/ cancers/breast-new.asp

2. Dunn, J, Occhipinti, S, Campbell A, Ferguson M, Chambers SK. Benefit Finding After Cancer: The Role of Optimism, Intrusive Thinking and Social Environment. Journal of Health 
Psychology 2011;16 (1):169-177.

3. Aarstad AK, Beisland E, Osthus AA, Aarstad HJ. Distress, quality of life, neuroticism and psychological coping are related in head and neck cancer patients during follow-up. Acta Oncologica 2011; 50 (3): 390-398.

4. Bal MD, Sahin NH. The effects of personality traits on quality of life. Menopause 2011; 18(12): 1309-1316.

5. Chochinov HM, Kristjanson LJ, Hack TF, Hassard T, McClement S, Harlos M. Personality, Neuroticism, and Coping Towards the End of Life. Journal of Pain \& Symptom Management 2006; 32 (4):332-341.

6. Butėnienè D., Kalibatienè D. Onkologinių pacientų gyvenimo kokybès ir vidinès darnos sąsajos esant paliatyviai priežiūrai. Medicinos teorija ir praktika, 2012;18 (4.1):452-460.

7. Rohani C, Abedi HA, Omranipour R, Langius-Eklöf A. Health-related quality of life and the predictive role of sense of coherence, spirituality and religious coping in a sample of Iranian women with breast cancer: a prospective study with comparative design. Health and Quality of Life Outcomes 2015; 13(1):40.

8. Danhauer SC, Crawford SL; Farmer DF; Avis NE. A longitudinal investigation of coping strategies and quality of life among younger women with breast cancer. J Behav Med 2009; 32(4):371-379.

\section{WOMEN WITH BREAST CANCER PERSONALITY TRAITS AND STRESS OF CAUSED ILLNESS COPING STRATEGIES COHERENCY WITH HEALTH LIFE QUALITY \\ I. Baniené, L. Šinkariova}

Key words: women, breast cancer, personality traits, stress coping strategies, health-related quality of life.

\section{Summary}

The aim of research - to identify woman with breast cancer coping with stress strategies, caused by the illness, and it's coherency with health-related quality of life. In this research were participating 102 women who have breast cancer. Respondents were selected by these criterions: female, I or II stage of cancer diagnosed, operational treatment was made 1 or 2 months ago, before operational treatment no chemotherapy or radiation therapy were made, first time treated for cancer illness, agreed on participating in research. In this research it was used these questionnaires: Eysenck's personality Inventory (EPI), Coping Orientation of Problem Experience test (COPE), EORTC Quality of Life Group life quality test EORTC QLQ - C30 and it‘s module EORTC QLQ - BR23. The results of research shown, that women with breast cancer, who's extraversion is characterized with higher rates, perceive their overall health-related quality of life and sexual functions as better ones, comparing with women distinguish by higher neurotic and psychotic indicators. Women who are using adaptive stress coping strategies their overall health-related quality of life, emotional, cognitive and sexual behavior perceived as better and feel less fear about future comparing with women who are using less adaptive stress coping strategies. Better overall health-related quality of life of women with breast cancer is explained by using adaptive directed to emotions defeat more often and less often using less adaptive defeat.

Correspondence to: baniene.irina@gmail.com 